\title{
Circulating hormones and hypothalamic energy balance: regulatory gene expression in the Lou/C and Wistar rats
}

\author{
Sharon E Mitchell, Ruben Nogueiras ${ }^{1}$, Kellie Rance, D Vernon Rayner, Sharon Wood, Carlos Dieguez ${ }^{1}$ \\ and Lynda M Williams
}

Obesity and Metabolic Health Division, Rowett Research Institute, Aberdeen AB21 9SB, UK

${ }^{1}$ Department of Physiology, University of Santiago de Compostela, 15705 Santiago de Compostela, Spain

(Requests for offprints should be addressed to L M Williams; Email: I.williams@rowett.ac.uk)

\begin{abstract}
To ascertain the mechanisms underlying low caloric intake and low body weight in the Lou/C rat, the circulating hormone levels and gene expression of hypothalamic peptides and receptors important in energy balance and the induction of suppressor of cytokine signalling 3 (SOCS3) gene expression in response to leptin challenge were compared with Wistar rats. Plasma leptin levels were lower in the Lou/C rat, as were levels of rat corticosterone, TSH and T4 but not T3. Ghrelin levels were higher in the Lou/C rat. Total leptin receptor $(\mathrm{Ob}-\mathrm{R})$ and the long form of the leptin receptor $(\mathrm{Ob}-\mathrm{Rb})$ gene expression were lower in the arcuate (ARC) and ventromedial nuclei (VMN) in Lou/C rat. Ghrelin receptor expression in the ARC and $\mathrm{VMN}$ was lower in Lou/C than in Wistar rats. However, agouti gene-related peptide (AgRP) and neuropeptide Y (NPY) gene expression
\end{abstract}

were higher in the Lou/C rat. There was no difference in the level of cocaine- and amphetamine-regulated transcript gene expression in the ARC, but both were higher in the paraventricular nuclei of the Lou/C breed. There was no difference in Ob-R gene expression in, or $\left[{ }^{125} \mathrm{I}\right]$ leptin binding to, the choroid plexus. SOCS3 mRNA induction in response to leptin was lower in the Lou/C rat. This study reveals that the comparatively low plasma leptin, TSH and T4 levels, and high ghrelin levels together with high levels of AgRP and NPY gene expression seen in the Lou/C rat are indicative of a strong drive to eat and decreased energy expenditure, which are in direct opposition to the comparatively low body weight and adiposity of this rat strain.

Journal of Endocrinology (2006) 190, 571-579

\section{Introduction}

Studies of rodents with either single gene mutations or gene knockouts have led to the discovery of a number of key components of the hypothalamic appetite and energy balance control system (Williams et al. 2001). Most of these rodent models have resulted in an obese phenotype, reflecting the multiplicity of the interrelated pathways that ensure the animal remains in homeostasis or in positive energy balance (Robinson et al. 2000). In contrast to these models, the Lou/C rat is an inbred sub-strain, derived from the Wistar rat. It is reported to exhibit spontaneous caloric restriction, relatively high energy expenditure and a lower body weight, mainly due to lower levels of white adipose tissue (WAT; Couturier et al. 2002, Perrin et al. 2003b). The Lou/C rat lives longer and does not develop insulin insensitivity, unlike the Wistar rat (Veyrat-Durebex \& Alliot 1997, Veyrat-Durebex et al. 1998), and is used as a model to study healthy ageing. Another model of low food intake, the anoretic mouse anx/ $a n x$, dies prematurely at 3-5 weeks of age from severe malnutrition as a result of an autosomal recessive mutation, which causes hypothalamic abnormalities and profound dysregulation of appetite and energy balance control mechanisms (Johansen et al. 2000). However, the hypothalamic mechanisms underlying the reported lower caloric intake and higher energy expenditure in the Lou/C rat are relatively unknown.

The major appetite and energy balance centres in the rodent consist of two distinct populations of neurons located in the arcuate (ARC) and ventromedial nuclei (VMN) of the hypothalamus (Kalra et al. 1999). One regulatory pathway consists of neurons co-expressing neuropeptide Y (NPY) and agouti gene-related protein (AgRP), potent stimulators of food intake, while an adjacent set of neurons co-express proopiomelanocortin (POMC) and cocaine- and amphetamine-regulated transcript (CART), which suppress food intake (Williams et al. 2001). These cells respond to peripheral hormones that signal both the long- and short-term energy status of the animal. Leptin, secreted by, and in proportion to, WAT enters the brain via the short forms of the leptin receptor (Ob-Ra and Ob-Rc; Bjorbaek et al. 1998). It then signals the status of energy stores by activating POMC/CART neurons and inhibiting NPY/AgRP neurons (Elias et al. 1999) via the long form of the leptin receptor (Ob-Rb; Mercer et al. 1996), 
resulting in inhibition of feeding and an increase in energy expenditure. In contrast, ghrelin, secreted mainly by the stomach but also present in the hypothalamus, activates the NPY/AgRP neurons (Kamegai et al. 2001, Cowley et al. 2003) via the ghrelin receptor (GHS-R; Guan et al. 1997) stimulating feeding and decreasing energy expenditure (Tang-Christensen et al. 2004b). Ghrelin, from the stomach, acts as a short-term signal of nutrient depletion; the levels rise in response to fasting and drop rapidly after feeding (Lee $e t$ al. 2002). However ghrelin in the hypothalamus is thought to link circadian rhythms and feeding activity (Cowley et al. 2003).

To determine if control mechanisms of energy balance may differ between the Lou/C and Wistar rats, we have compared the levels of circulating hormones and the gene expression of hypothalamic peptides and receptors important in energy balance in these sub-species. These include: $\mathrm{Ob}-\mathrm{R}$ (all forms of the leptin receptor), GHS-R, AgRP, NPY and CART. We have also compared the levels of $\left[{ }^{125} \mathrm{I}\right]$ leptin binding to the choroid plexus to ascertain if leptin transport into the cerebrospinal fluid (CSF) may differ between the two substrains of rat. Furthermore, to determine if polymorphisms in the promoter region of GHS-R may be responsible for differences in the level of expression of GHS-R in the ARC and VMN of the Lou/C rat, this region of the gene was sequenced in both sub-strains. Finally, to ascertain whether sensitivity to the leptin signal is different between these rats, we have challenged Lou/C and Wistar rats with a single i.p. leptin injection and measured the induction of suppressor of cytokine signalling 3 (SOCS3) gene expression in the ARC $1 \mathrm{~h}$ later.

\section{Materials and Methods}

\section{Experimental animals}

All studies involving animals were licensed under the Animal (Scientific Procedures) Act of 1986 and received approval from the Rowett Research Institute's Ethical Review Committee. Lou/C and Wistar rats (Harlan, Blackthorn, Oxon, UK) were housed at the Rowett Research Institute for 3 weeks prior to experiment under a controlled $12 \mathrm{~h}$ light: $12 \mathrm{~h}$ darkness cycle at $21-22^{\circ} \mathrm{C}$ and fed standard rat chow and water ad libitum. Rats were weighed and cumulative food intake was measured three times a week.

\section{Leptin challenge}

On the day of experiment, rats were randomly divided into groups (each $n=6$ ) within each sub-strain. Rats received either a single i.p. injection of leptin $(2 \mathrm{mg} / \mathrm{kg}$ body weight) or a carrier solution. Rats were killed $1 \mathrm{~h}$ after injection by terminal anaesthesia followed by decapitation, with trunk blood collected into heparinised tubes on ice. Brains were removed, frozen in isopentane, chilled over dry ice and stored at $-80{ }^{\circ} \mathrm{C}$ until cryo-sectioned and processed for in situ hybridisation or quantitative in vitro autoradiography. Subcutaneous, epididymal, retroperitoneal, mesenteric and omental WAT depots and intrascapular brown adipose tissue (BAT) and the gastrocnemius and soleus muscles of the right leg were removed, weighed and frozen in liquid nitrogen.

\section{In situ hybridisation}

Specific probes for GHS-R, Ob-R, Ob-Rb, AgRp, NPY, CART and SOCS3 were used as detailed previously (Adam et al. 2000, Mercer et al. 2000, Nogueiras et al. 2004, Tups et al. 2004). Automated sequencing was performed to verify each sequence. Messenger RNA levels were quantified using these probes by in situ hybridisation, on $20 \mu \mathrm{m}$ thick coronal hypothalamic sections, using techniques described in detail elsewhere (Mitchell et al. 2002). Briefly, slides were fixed in $4 \%(\mathrm{w} / \mathrm{v})$ paraformaldehyde in PBS $(0.1 \mathrm{~mol} / \mathrm{l}$ phosphate buffer $/ 0 \cdot 9 \%(\mathrm{w} / \mathrm{v})$ saline) for $20 \mathrm{~min}$ at room temperature, washed in PBS, incubated in $0.1 \mathrm{mmol} / 1$ triethanolamine for $2 \mathrm{~min}$ and acetylated in $0.1 \mathrm{mmol} / \mathrm{l}$ triethanolamine and $0 \cdot 25 \%(\mathrm{v} / \mathrm{v})$ acetic anhydride for $10 \mathrm{~min}$. Sections were dehydrated in ethanol and dried under vacuum before hybridisation with riboprobes at $10^{6}$ c.p.m. $/ \mathrm{ml}$ for $18 \mathrm{~h}$ at $58{ }^{\circ} \mathrm{C}$. After hybridisation, sections were desalted through a series of washes in SSC to a final stringency of $0 \cdot 1 \times$ SSC at $60{ }^{\circ} \mathrm{C}$ for $30 \mathrm{~min}$, treated with RNase A and dehydrated in ethanol. Slides were apposed to Biomax MR (Sigma) together with $\left[{ }^{14} \mathrm{C}\right]$ microscale standards (Amersham International) at room temperature for varying lengths of time depending on the probes used.

\section{In vitro autoradiography}

Sections were acid prewashed in low $\mathrm{pH}$, highsalt $(\mathrm{pH} 2$, $0 \cdot 5 \mathrm{M} \mathrm{NaCl}$ ) HEPES buffer, to remove any endogenous leptin bound to its receptor, prior to a brief wash in HEPES before incubation with $1 \mathrm{nM}\left[{ }^{125} \mathrm{I}\right]$ leptin with the specific activity adjusted to 250000 c.p.m./pM in HEPES for $2 \mathrm{~h}$ at room temperature. Control slides were incubated with $\left.{ }^{125} \mathrm{I}\right]$ leptin as plus $1 \mu \mathrm{M}$ leptin. Slides were then thoroughly washed in HEPES buffer followed by distilled water at $4{ }^{\circ} \mathrm{C}$ and airdried before apposed to Biomax MR (Sigma) together with $\left[{ }^{125} \mathrm{I}\right]$ microscale standards (Amersham International) at room temperature.

Quantification of in situ hybridisation and in vitro autoradiography

Autoradiographs were scanned on Umax Power Look II (UMAX Data Systems, Fremont, CA, USA). Integrated optical densities, measurements of both surface area and optical density of images, were quantified using the Image Pro-plus system (Media Cybernetics, Silver Springs, MD, USA) and converted to nanocurie per gram using $\left[{ }^{14} \mathrm{C}\right]$ microscale standard curves. For quantification of $\left[{ }^{125} \mathrm{I}\right]$ leptin 
binding to the choroid plexus, average optical densities were measured and converted to nanocurie per gram using $\left[{ }^{125} \mathrm{I}\right]$ microscale standard curves.

\section{Immunoassays for plasma hormone levels}

Serum leptin and ghrelin concentrations were measured using commercially available rat-specific RIA kits (Linco Research Inc., St Charles, MI, USA and Pheonix Diagnostics Inc., Belmont, CA, USA, respectively). Serum T3, T4 and corticosterone were measured by ELISA (Diagnostic Automation Inc., Calabasas, CA, USA and Assay Designs, Ann Arbor, MI, USA, respectively). Insulin was measured using a Luminex 100 analyser and a rat endocrine Lincoplex kit (Linco Research Inc).

Thyroid-stimulating hormone (TSH) was measured by RIA as previously described (Seoane et al. 2000) using reagents provided by the National Hormone and Peptide Program (NHPP; Torrance, CA, USA).

\section{Sequencing of the GHS-R promoter region}

Genomic DNA was extracted from frozen muscle samples of two Wistar and Lou/C rats using DNeasy tissue (Qiagen). The $5^{\prime}$-flanking region of the GHS-R was amplified using PCR primers designed using PrimerSelect computer software (DNASTAR, Madison, WI, USA) based on Genbank Rattus norvegicus nucleotide sequence data no. NW047624. The region from -2682 to +475 bp relative to the rat GHS-R translation start site was amplified $\left(96^{\circ} \mathrm{C}\right.$ for $30 \mathrm{~s}, 68^{\circ} \mathrm{C}$ for $60 \mathrm{~s}, 72^{\circ} \mathrm{C}$ for $45 \mathrm{~s}, 35$ cycles) using F1 (5'-TCC CAT GCT TGT TTG CTT TGT GAC) and R1 ( $5^{\prime}$-ACG CGG CCC TTA GTG ACC A) as primers. The resultant PCR product was sequenced using a CEQ 8000 genetic analysis system (Beckman Coulter, Inc., Fullerton, CA, USA) and the internal primers iF2 (5'-AGC GCT GGC CTC TAC CTT), iF3 (5'-GCC CCC TAC TGC TTC TTG ATA ACA), iF4 (5'-GCT GGC CGA GGT GCT GAA GA), iF5 (5'-GGC TTC CGC ACT TGT TAC) and iF6 (5'-GGC GCT GCT CCG GTG ATA GG).

\section{Statistical analysis}

Data are represented as means \pm S.E.M. and analysed by oneway ANOVA. $P<0 \cdot 05$ was considered statistically significant.

\section{Results}

\section{Body weights, food intake and circulating hormone levels}

In the present study, Lou/C rats had a significantly lower body weight than the age-matched Wistar rats $(P<0 \cdot 001$; Fig. 1a) and also ate significantly less food $(P<0 \cdot 001$; Fig. 1b). Tissues measured weighed less in the Lou/C rat $(P<0 \cdot 05$; data not shown), but when calculated relative to whole body weight, total WAT depots were at a lower percentage of body weight in the Lou/C rat $(P<0 \cdot 001$; Fig. 1c). BAT $(P<0 \cdot 001$; Fig. 1d) and the two muscles sampled were equivalent to (NS, no significant difference) or at a higher percentage of body weight $(P<0 \cdot 001)$ compared with the Wistar rat (Fig. 1e). Thus, the Lou/C rat is also leaner than the Wistar rat.

In vehicle-treated animals, serum leptin levels were significantly lower in the Lou/C rats $(P<0 \cdot 05$; Fig. 2a), which is to be expected from the significantly lower weights of all WAT depots measured. Serum ghrelin levels were higher in the Lou/C rat $(P<0 \cdot 001$; Fig. $2 \mathrm{~b})$, but there was no significant difference in insulin levels between the two substrains (Fig. 2c). TSH and T4 were lower in the Lou/C rat $(P<0 \cdot 05$ and $P<0 \cdot 01$, respectively), although T3 concentrations were similar (Fig. $2 \mathrm{~d}-\mathrm{f}$ ). Corticosterone was lower in the Lou/C rat $(P<0 \cdot 01$; Fig. $2 \mathrm{~g})$.

\section{Hypothalamic peptides and receptor gene expression}

In vehicle-treated animals, measurement of gene expression with a probe that recognises all isoforms of the leptin receptor, $\mathrm{Ob}-\mathrm{R}$, revealed significant differences, with lower levels of Ob-R gene expression present in the ARC $(P<0 \cdot 001)$ and the VMN $(P<0 \cdot 05)$ of the Lou/C compared with the Wistar rat (Fig. 3a). The same pattern was also seen with the probe for the long signalling form of the receptor $(\mathrm{Ob}-\mathrm{Rb})$, which showed lower levels of gene expression in the ARC $(P<$ $0 \cdot 01)$ and $\operatorname{VMN}(P<0 \cdot 05)$ in the Lou/C rat (Fig. 3b). GHS$\mathrm{R}$ gene expression was found to be lower in both the ARC $(P<0 \cdot 001)$ and the VMN $(P<0 \cdot 001)$ of the Lou/C rats compared with the Wistar rat (Fig. 3c). In contrast, the levels of both AgRP $(P<0 \cdot 001)$ and NPY $(P<0 \cdot 001)$ gene expression in the ARC were higher in the Lou/C rat compared with the Wistar rat (Fig. 3d). While the level of CART gene expression in the ARC was not different between the two sub-strains, in the paraventricular nuclei $(\mathrm{PVN})$, levels of CART mRNA were higher $(P<0 \cdot 001)$ in the Lou/C compared with the Wistar rat (Fig. 3e).

\section{Leptin receptor expression and $\left[{ }^{125}\right.$ I]leptin binding to the choroid} plexus

Ob-R gene expression was also measured in two distinct regions of the choroid plexus of the lateral ventricle, one central and lateral. At neither site was there a difference between the vehicle-treated sub-strains of rat (Fig. 4a). The level of specific binding of $\left[{ }^{125} \mathrm{I}\right]$ leptin to the same regions of the choroid plexus was also similar between the two substrains (Fig. 4b).

\section{SOCS3 gene expression}

Leptin challenge did not give rise to a significant change in SOCS3 expression, $1 \mathrm{~h}$ after leptin challenge, in the ARC of 


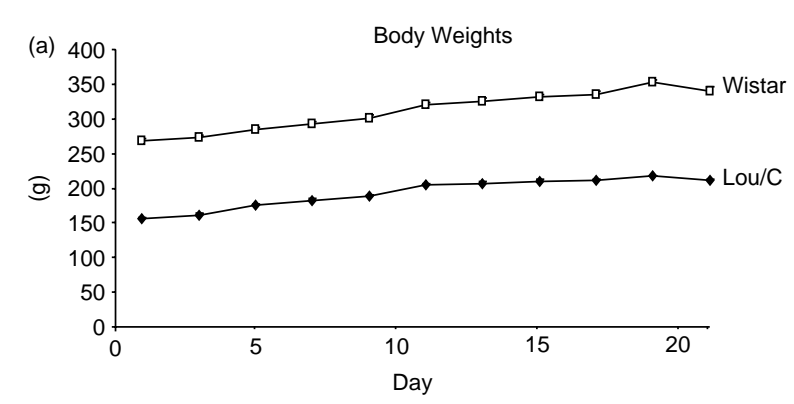

(b)
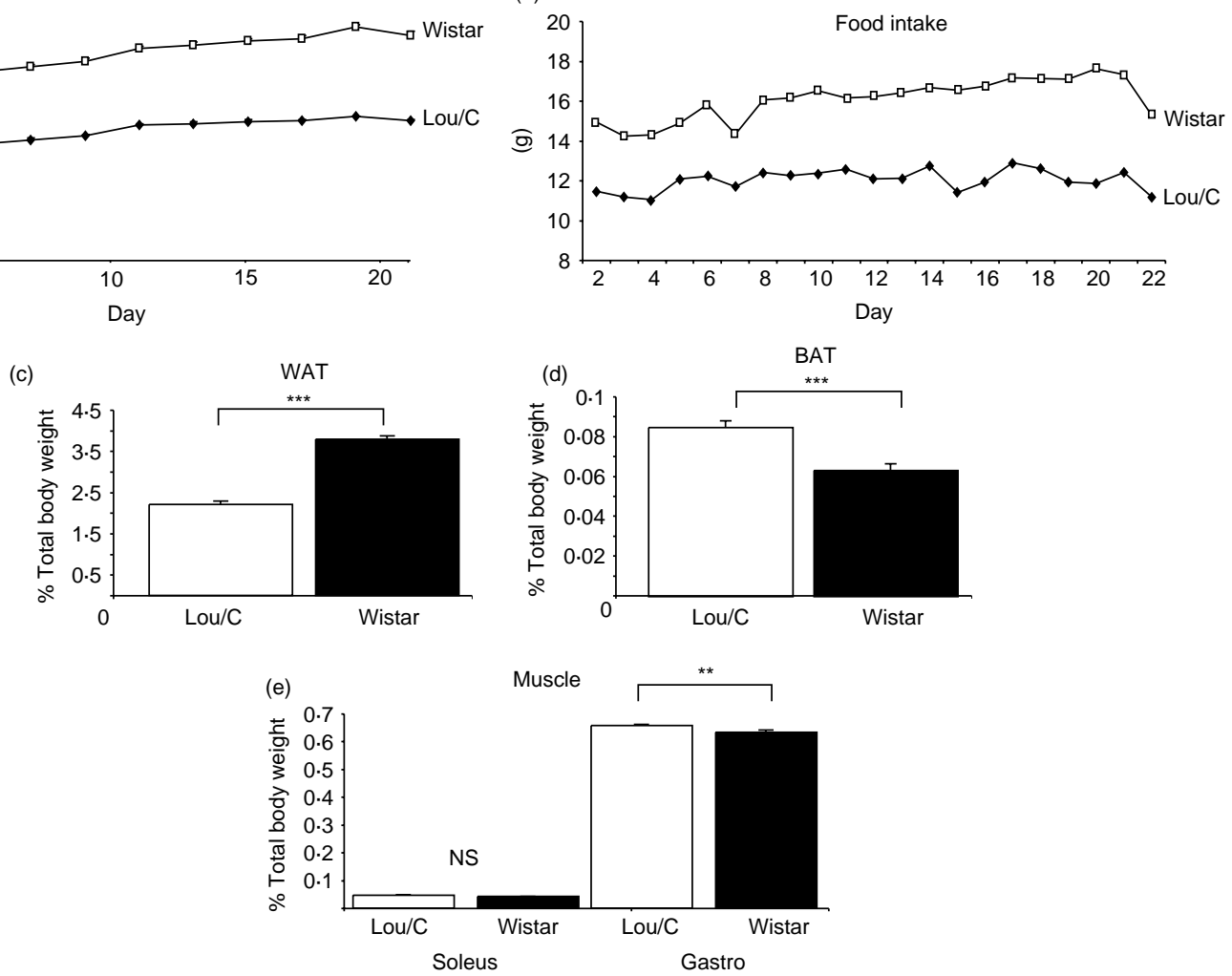

Figure 1 (a) Body weights of Lou/C rats compared with Wistar rats $(P<0 \cdot 001)$. For all points S.E.M. is too small to be visible on graph. (b) Food intakes of Lou/C rats compared with Wistar rats $(P<0 \cdot 001)$. (c) Relative weights (g/100 g body weight) of total dissected white adipose tissue (WAT) depots, $* * * P<0 \cdot 001$; (d) brown adipose tissue (BAT), $* * * P<0 \cdot 001$, and (e) soleus and gastrocnemius muscle, ${ }^{* * P}<0 \cdot 01$, in Lou/C and Wistar rats $(n=12)$. NS, no significant difference.

the Lou/C rat. However, in the Wistar rat, SOCS3 expression, $1 \mathrm{~h}$ after leptin challenge, was significantly elevated $(P<0 \cdot 01)$ compared with basal levels. Interestingly, while circulating leptin was lower $(P<0 \cdot 05$; Fig. 2a) in the Lou/C rat compared with the Wistar rat, the basal level of SOCS3 gene expression was not significantly different (Fig. 5). Any potential response to leptin challenge was also tested for by investigating changes in the level of all the hypothalamic genes detailed, and for specific $\left[{ }^{125}\right.$ I] leptin binding to the choroid plexus. At $1 \mathrm{~h}$ after leptin challenge, there was no significant change in the level of expression of any of the genes or in $\left[{ }^{125} \mathrm{I}\right]$ leptin binding in either of the substrains (data not shown).

\section{GHS-R promoter sequence}

Full-length consensus sequences were formed using SeqMan (DNASTAR, Madison, WI, USA) for Lou/C and Wistar rats. Analysis of the consensus sequences using Megalign (DNASTAR) showed complete alignment of Lou/C and Wistar sequences (accession no. AY940035). This suggests that polymorphism within the Lou/C GHS-R promoter is not responsible for the lower level of GHS-R seen in the
Lou/C rat. There were four incidences of single nucleotide polymorphisms (SNP) between accession no. NW047624, obtained from Brown Norway rats, and our sequences. However, these instances of SNPs are not unexpected as considerable genetic variation has previously been observed between Brown Norway compared with Lou/C and Wistar rats (Smits et al. 2004).

\section{Discussion}

The Lou/C rat maintains a relatively low body weight throughout its lifetime by naturally restricting its caloric intake and expending more energy (Perrin et al. 2003a, 2003b). The body weights and food intakes, plus plasma leptin and ghrelin levels, measured in the present study confirm those obtained previously, defining the Lou/C rat as a model of low body weight (Alliot et al. 2002, Couturier et al. 2002, Perrin et al. 2003b). TSH and T4 levels were lower in the Lou/C rat, although T3 levels were not significantly different, indicating central hypothyroidism that would act to limit energy expenditure in response to low body weight and low serum leptin levels. Corticosterone is permissive for appetite 

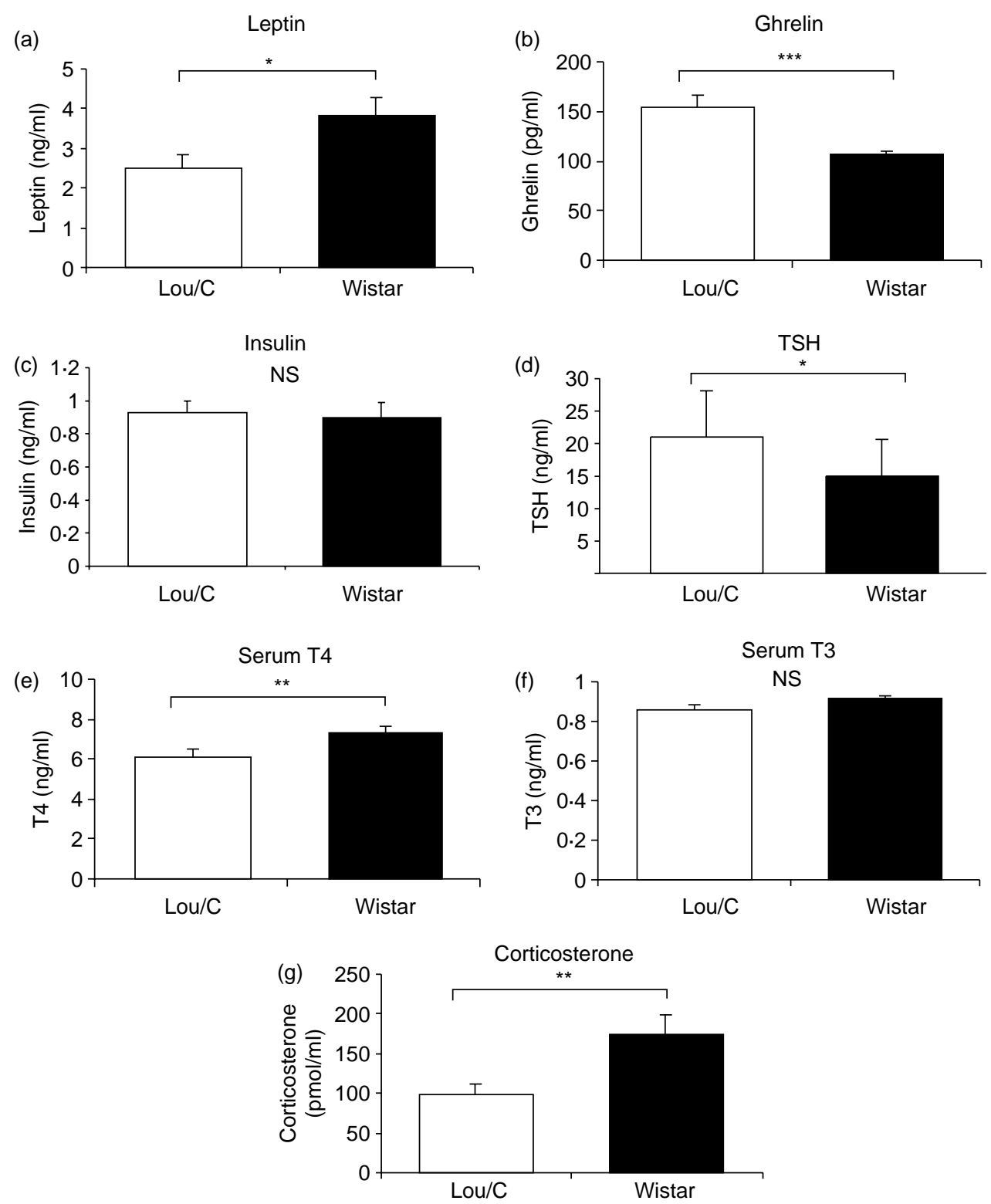

Figure 2 Plasma hormone levels in control animals. (a) Leptin Lou/C versus Wistar, $* P<0 \cdot 05$. (b) Ghrelin Lou/C versus Wistar, ${ }^{* * *} P<0 \cdot 001$. (c) Insulin Lou/C versus Wistar; NS, no significant difference. (d) TSH Lou/C versus Wistar, ${ }^{*} P<0 \cdot 05$. (e) T4 Lou/C versus Wistar, ${ }^{* *} P<0 \cdot 01$. (f) T3 Lou/C versus Wistar; NS, no significant difference. (g) Corticosterone Lou/C versus Wistar, $* * P<0 \cdot 01(n=6)$.

stimulation and body fat accumulation, and the higher levels observed in the Wistar rat may stimulate adiposity via the actions of hormones such as ghrelin (Tung et al. 2004). Thus, the lower levels of plasma corticosterone levels in the Lou/C may contribute to their lower levels of WAT.

Relatively little is known of the hypothalamic mechanisms underlying the differences in caloric intake and energy expenditure between the Lou/C and the closely related Wistar rat. A comparison of four different strains of rat, employing semi-quantitative reverse transcriptase (RT)-PCR on whole hypothalamic explants, reported no differences in AgRP, NPY, Ob-Rb or GHS-R gene expression between Lou/C and Wistar rats (Kappler et al. 2004). However, a subsequent study using the same techniques observed increased levels of gene expression for some orexigenic peptides in the Lou/C rat compared with the Wistar. Nevertheless, these differences appeared in the older rats with little or no differences for younger animals (12 weeks of age), except for orexin (Kappler et al. 2003). While RT-PCR in these studies measured total gene expression within the 

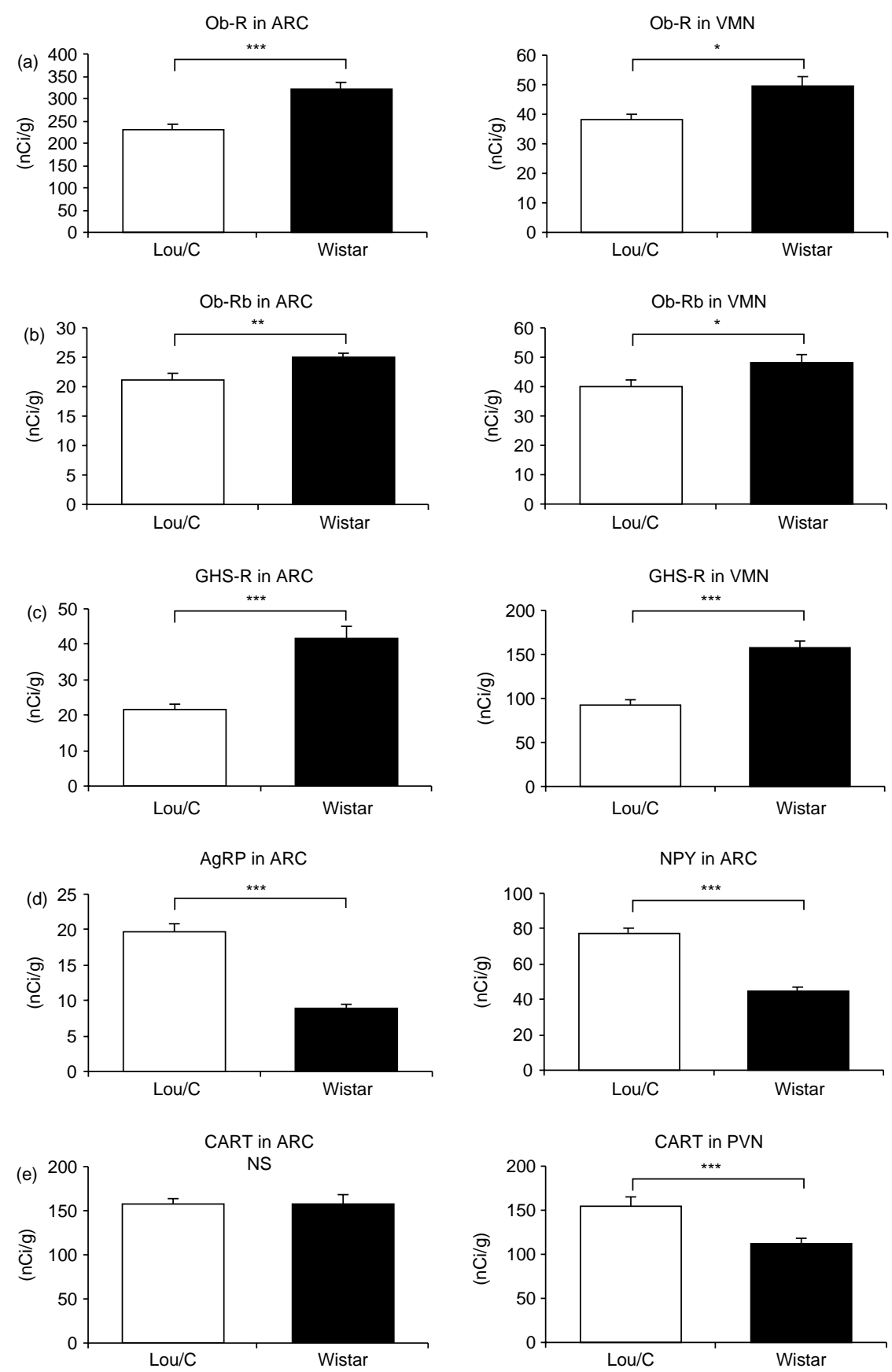

Figure 3 (a) Ob-R gene expression in the ARC and $V M N, * * * P<0.001$ and $* P<0 \cdot 05$, respectively, for Lou/C versus Wistar rats. (b) Ob-Rb gene expression in the ARC and VMN, $* * P<0 \cdot 01$ and $* P<0 \cdot 05$, respectively, for Lou/C versus Wistar rats. (c) GHS-R gene expression in the ARC and $\mathrm{VMN}, * * * P<0.001$ for Lou/C versus Wistar in both nuclei. (d) AgRP and NPY gene expression in the ARC, $* P<, 0.001$ for Lou/C versus Wistar for both peptides. (e) CART gene expression in the ARC and PVN; NS, no significant difference and $* * * P<0 \cdot 001$, respectively, for Lou/C versus Wistar $(n=6)$. 


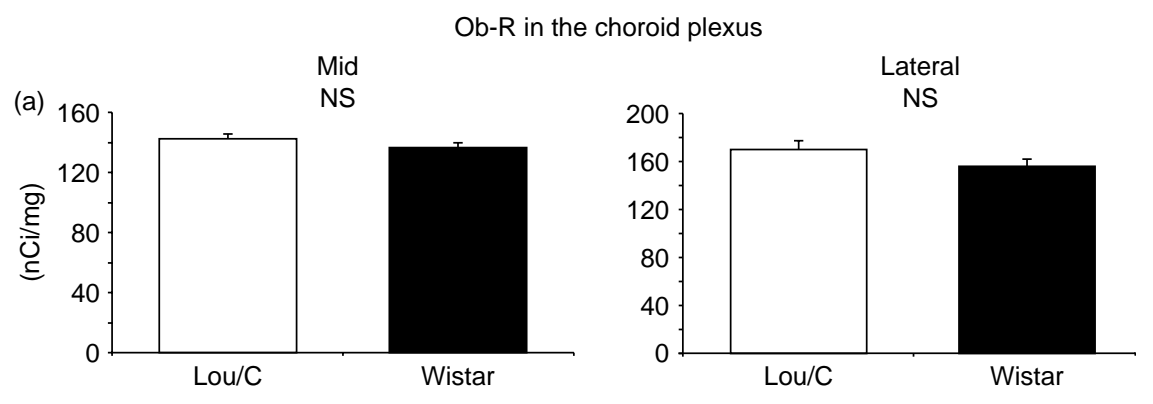

[125I] leptin binding to the choroid plexus

(b)

Mid

NS

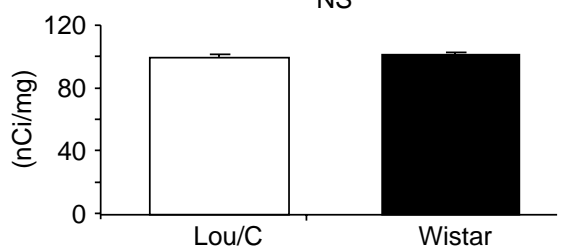

Lateral

NS

Figure 4 (a) Ob-R gene expression in two regions, mid and lateral of the choroid plexus (CP). Lou/C versus Wistar; NS, no significant difference. (b) Density of $\left[{ }^{125} I\right]$ leptin binding in the same two regions of the CP. Lou/C versus Wistar; NS, no significant difference $(n=6)$.

hypothalamus, it cannot distinguish between different nuclei. In the present study, we have used quantitative in situ hybridisation to compare levels of gene expression in the hypothalamic energy balance centres of the Lou/C and Wistar rats enabling us to identify differences in individual nuclei.

The level of expression of leptin receptors, measured using a probe that recognises all forms of the receptor, was significantly lower in the ARC and the VMN in the Lou/C rat. This finding was confirmed using a probe specific for the long signalling form of the receptor $(\mathrm{Ob}-\mathrm{Rb})$. The lower levels of $\mathrm{Ob}-\mathrm{R}$ and $\mathrm{Ob}-\mathrm{Rb}$ mRNA indicate that less leptin receptors are available in these nuclei. This would make the Lou/C less sensitive to the effects of leptin, as confirmed by the negligable induction of SOCS3 gene expression $1 \mathrm{~h}$ after a single i.p. injection of leptin, indicating that the Lou/C rat probably has both lower amounts of the leptin receptor and a lower sensitivity to leptin. This would be contrary to the

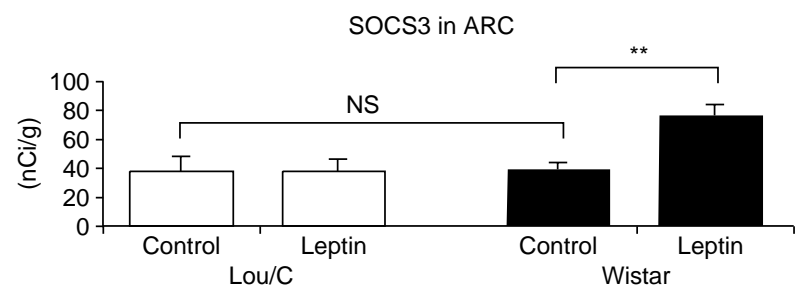

Figure 5 SOCS3 gene expression in the ARC in response to a single i.p. leptin injection, ${ }^{* *} P<0 \cdot 01$ Wistar control versus Wistar leptin; NS, no significant difference for Lou/C control versus $\mathrm{Lou} / \mathrm{C}$ leptin or for Lou/C control versus Wistar control $(n=6)$. known effects of leptin in regulating WAT accumulation, whereby animals with higher levels of WAT are usually less sensitive to leptin (Levin \& Dunn-Meynell 2002). However, SOCS3 inhibits the signalling of the leptin receptor via the janus kinase/signal transducer and activator of transcription 3 (JAK/STAT3) pathway (Bjorbaek et al. 2000), with SOCS3 haploinsufficiency resulting in greater sensitivity to the leptin signal and a lower body weight (Howard et al. 2004, Mori et al. 2004). Therefore, a lower level of SOCS3 induction by leptin challenge as seen in the $\mathrm{Lou} / \mathrm{C}$ rat may indicate that the JAK/STAT3 signalling pathway is not as efficiently inhibited in comparison to the Wistar rat. However, the lower level of circulating TSH and T4 found in the Lou/C could be explained by both the lower leptin levels and a lower sensitivity to leptin. In this regard, it is well established that decreased TSH and T4 levels during food deprivation can be reversed following leptin administration. The blunted TSHthyroid axis in this setting is due to decrease synthesis of thyrotrophin-releasing hormone at hypothalamic levels (Fekete et al. 2006). Taken together, our findings indicate that Lou/C rats exhibit biochemical features of central hypothyroidism as an adaptative mechanism to decrease energy expenditure in the face of low energy stores. Further studies are needed to clarify the relative sensitivities of the Lou/C and Wistar rats to leptin.

The lack of difference between the sub-strains in Ob-R gene expression and in the level of $\left[{ }^{125} \mathrm{I}\right]$ leptin binding to the choroid plexus indicates that leptin transport across the choroid plexus into the CSF is similar, as defined by the ability of the receptor protein to bind to its ligand in this region. 
However, this study does not provide data on the transport process itself or on the transport of leptin across the bloodbrain barrier of the microvessels of the brain.

A striking difference between the Lou/C and the Wistar rats was the lower level of GHS-R expression found in the ARC and the VMN in the Lou/C rat. GHS-R gene expression in the hypothalamus has been shown to be controlled by numerous circulating hormones and nutritional factors (Bennett et al. 1997, Tamura et al. 2000, Petersenn et al. 2001, Kim et al. 2003, Nogueiras et al. 2004), including leptin and ghrelin, the former downregulating and the latter upregulating gene expression in the ARC (Nogueiras et al. 2004). In the Lou/C rat, leptin levels are relatively low, while ghrelin levels are relatively high compared with the Wistar rat. This might be expected to result in higher levels of GHS-R in the Lou/C rat, contrary to what was observed. GHS-R gene expression is also modulated by both thyroid hormones and glucocorticoids (Thomas et al. 2000), with adrenalectomy downregulating gene expression and dexamethasone treatment reinstating normal levels of GHS-R expression. Therefore, the lower levels of corticosterone seen in the Lou/C rat could explain the reduced levels of GHS-R, and indicate that corticosterone is more influential than ghrelin or leptin in controlling this expression. This hypothesis remains to be tested. One possibility excluded by this study was that mutations in the promoter region of the GHS-R gene were responsible for the different level of GHS-R expression in the two sub-strains.

Ghrelin signals to the hypothalamus to increase food intake and to decrease energy expenditure (Tschop et al. 2000, Holst et al. 2003, Holst \& Schwartz 2004). If the lower levels of GHS-R gene expression were related to less receptor protein, a reduced response to the orexigenic effects of ghrelin may result. This could offer an explanation for the lower body weight in the Lou/C rat, particularly as the GHS-R has been shown to be constitutively active in transfected cells (Holst et al. 2003), with the level of GHS-R gene expression being postulated as providing a set point in appetite and energy balance control (Holst \& Schwartz 2004). Nonetheless, ghrelin is known to act largely by increasing AgRP and NPY gene expression (Kamegai et al. 2001, Tang-Christensen et al. 2004a), and mRNA abundance of both of these peptides was higher in the Lou/C rat compared with the Wistar rat. Increased AgRP and NPY should signal that the Lou/C rat is in a state of caloric deficit and provoke increased food intake and decreased energy expenditure. This clearly does not occur; these signals are either not being read or are being overridden. In this latter respect, it is interesting that levels of the anorexigenic peptide CART were higher in the PVN, but not the ARC of the Lou/C rat. This may override the AgRP and NPY signals to limit caloric intake in the Lou/C rat.

In summary, the levels of circulating hormones and hypothalamic expression of genes controlling food intake and energy expenditure in the Lou/C rat differ from those in the closely related Wistar rat. However, the differences in the gene expression of hypothalamic peptides and receptors are largely contrary to those predicted from the adiposity of the sub-strains. Comparative studies involving manipulation of energy intake and its impact on circulating hormones and hypothalamic gene expression involved in energy balance are presently being carried out to elucidate the mechanisms underlying the maintenance of low adiposity in the Lou/C rat.

\section{Funding}

This work was supported by the Ministerio de Ciencia y Tecnologia in Spain and the Scottish Executive Environment and Rural Affairs Department in the Sharon Mitchell was funded by EC Framework V Grant QLK6-2002-02288. Rubén Nogueiras was a recipient of a Research Training Grant at Obes ${ }^{\mathrm{e}}$ chool funded by EC Framework V Program HPMT-CT-2001-00410. The authors declare that there is no conflict of interest that would prejudice the impartiality of this scientific work.

\section{References}

Adam CL, Moar KM, Logie TJ, Ross AW, Barrett P, Morgan PJ \& Mercer JG 2000 Photoperiod regulates growth, puberty and hypothalamic neuropeptide and receptor gene expression in female Siberian Hamsters. Endocrinology 141 4349-4356.

Alliot J, Boghossian S, Jourdan D, Veyrat-Durebex C, Pickering G, MeynialDenis D \& Gaumet N 2002 The LOU/c/jall rat as an animal model of healthy aging? Journals of Gerontology. Series A, Biological Sciences and Medical Sciences 57 B312-B320.

Bennett PA, Thomas GB, Howard AD, Feighner SD, VanderPloeg LHT, Smith RG \& Robinson ICAF 1997 Hypothalamic growth hormone secretagogue-receptor (GHS-R) expression is regulated by growth hormone in the rat. Endocrinology 138 4552-4557.

Bjorbaek C, Elmquist JK, Michl P, Ahima RS, van Bueren A, McCall AL \& Flier JS 1998 Expression of leptin receptor isoforms in rat brain microvessels. Endocrinology 139 3485-3491.

Bjorbaek C, Lavery HJ, Bates SH, Olson RK, Davis SM, Flier JS \& Myers MG 2000 SOCS3 mediates feedback inhibition of the leptin receptor via Tyr(985). Journal of Biological Chemistry 275 40649-40657.

Couturier K, Servais S, Koubi H, Sempore B, Sornay-Mayet MH, Cottet-Emard JM, Lavoie JM \& Favier R 2002 Metabolic characteristics and body composition in a model of anti-obese rats (Lou/C). Obesity Research 10 188-195.

Cowley MA, Smith RG, Diano S, Tschop M, Pronchuk N, Grove KL, Strasburger CJ, Bidlingmaier M, Esterman M, Heiman ML et al. 2003 The distribution and mechanism of action of ghrelin in the CNS demonstrates a novel hypothalamic circuit regulating energy homeostasis. Neuron 37 649-661.

Elias CF, Aschkenasi C, Lee C, Kelly J, Ahima RS, Bjorbaek C, Flier JS, Saper CB \& Elmquist JK 1999 Leptin differentially regulates NPY and POMC neurons projecting to the lateral hypothalamic area. Neuron 23 775-786.

Fekete C, Singru PS, Sanchez E, Sarkar S, Christoffolete MA, Riberio RS, Rand WM, Emerson CH, Bianco AC \& Lechan RM 2006 Differential effects of central leptin, insulin, or glucose administration during fasting on the hypothalamic-pituitary-thyroid axis and feeding-related neurons in the arcuate nucleus. Endocrinology 147 520-529.

Guan XM, Yu H, Palyha OC, Mckee KK, Feighner SD, Sirinathsinghji DJS, Smith RG, VanderPloeg LHT \& Howard AD 1997 Distribution of mRNA encoding the growth hormone secretagogue receptor in brain and peripheral tissues. Molecular Brain Research 48 23-29. 
Holst B \& Schwartz TW 2004 Constitutive ghrelin receptor activity as a signaling set-point in appetite regulation. Trends in Pharmacological Sciences 25 113-117.

Holst B, Cygankiewicz A, Jensen TH, Ankersen M \& Schwartz TW 2003 High constitutive signaling of the ghrelin receptor - identification of a potent inverse agonist. Molecular Endocrinology 17 2201-2210.

Howard JK, Cave BJ, Oksanen LJ, Tzameli I, Bjorbaek C \& Flier JS 2004 Enhanced leptin sensitivity and attenuation of diet-induced obesity in mice with haploinsufficiency of Socs3. Nature Medicine 10 734-738.

Johansen JE, Broberger C, Lavebratt C, Johansson C, Kuhar MJ, Hokfelt T \& Schalling M 2000 Hypothalamic CART and serum leptin levels are reduced in the anorectic (anx/anx) mouse. Molecular Brain Research 84 97-105.

Kalra SP, Dube MG, Pu S, Xu B, Horvath TL \& Kalra PS 1999 Interacting appetite-regulating pathways in the hypothalamic regulation of body weight. Endocrine Reviews 20 68-100.

Kamegai J, Tamura H, Shimizu T, Ishii S, Sugihara H \& Wakabayashi I 2001 Chronic central infusion of ghrelin increases hypothalamic neuropeptide $\mathrm{Y}$ and agouti-related protein mRNA levels and body weight in rats. Diabetes $502438-2443$.

Kappler L, Zizzari P, Bluet-Pajot MT, Bassant MH, Poindessous F, Alliot J \& Epelbaum J 2003 Neuroendocrine and gene expression variations along aging in Wistar and Lou/C/Jall. Journal of Nutrition, Health and Aging 17 230.

Kappler L, Zizzari P, Grouselle J, Epelbaum J \& Bluet-Pajot MT 2004 Plasma and hypothalamic peptide-hormone levels regulating somatotroph function and energy balance in fed and fasted states:a comparative study in four strains of rats. Journal of Neuroendocrinology 16 980-988.

Kim MS, Yoon CY, Park KH, Shin CS, Park KS, Kim SY, Cho BY \& Lee HK 2003 Changes in ghrelin and ghrelin receptor expression according to feeding status. Neuroreport 14 1317-1320.

Lee HM, Wang GY, Englander EW, Kojima M \& Greeley GH 2002 Ghrelin, a new gastrointestinal endocrine peptide that stimulates insulin secretion: enteric distribution, ontogeny, influence of endocrine, and dietary manipulations. Endocrinology 143 185-190.

Levin BE \& Dunn-Meynell AA 2002 Reduced central leptin sensitivity in rats with diet-induced obesity. American Journal of Physiology 283 R 941-R 948.

Mercer JG, Hoggard N, Williams LM, Lawrence CB, Hannah LT \& Trayhurn P 1996 Localization of leptin receptor mRNA and the long form splice variant $(\mathrm{Ob}-\mathrm{Rb})$ in mouse hypothalamus and adjacent brain regions by in situ hybridization. FEBS Letters 387 113-116.

Mercer JG, Moar KM, Ross AW, Hoggard N \& Morgan PJ 2000 Photoperiod regulates arcuate nucleus POMC, AGRP, and leptin receptor mRNA in Siberian Hamster hypothalamus. American Journal of Physiology 278 R271-R281.

Mitchell SE, Robinson JJ, King ME, McKelvey WAC \& Williams LM 2002 Interleukin 8 in the cervix of non-pregnant ewes. Reproduction 124 409-416.

Mori H, Hanada R, Hanada T, Aki D, Mashima R, Nishinakamura H, Torisu T, Chien KR, Yasukawa H \& Yoshimura A 2004 Socs3 deficiency in the brain elevates leptin sensitivity and confers resistance to dietinduced obesity. Nature Medicine 10 739-743.

Nogueiras R, Tovar S, Mitchell SE, Rayner DV, Archer ZA, Dieguez C \& Williams LM 2004 Regulation of growth hormone secretagogue receptor gene expression in the arcuate nuclei of the rat by leptin and ghrelin. Diabetes 53 2552-2558.
Perrin D, Mamet J, Geloen A, Morel G, Dalmaz Y \& Pequignot JM $2003 a$ Sympathetic and brain monoaminergic regulation of energy balance in obesity-resistant rats (Lou/C). Autonomic Neuroscience: Basic and Clinical 109 1-9.

Perrin D, Soulage C, Pequignot JM \& Geloen A $2003 b$ Resistance to obesity in Lou/C rats prevents ageing-associated metabolic alterations. Diabetologia 46 1489-1496.

Petersenn S, Rasch AC, Penshorn M, Beil FU \& Schulte HM 2001 Genomic structure and transcriptional regulation of the human growth hormone secretagogue receptor. Endocrinology 142 2649-2659.

Robinson SW, Dinulescu DM \& Cone RD 2000 Genetic models of obesity and energy balance in the mouse. Annual Review of Genetics 34 687-745.

Seoane LM, Carro E, Tovar S, Casanueva FF \& Dieguez C 2000 Regulation of in vivo TSH secretion by leptin. Regulatory Peptides 92 25-29.

Smits BMG, van Zutphen BFM, Plasterk RHA \& Cuppen E 2004 Genetic variation in coding regions between and within commonly used inbred rat strains. Genome Research 14 1285-1290.

Tamura H, Kamegai J, Sugihara H, Kineman RD, Frohman LA \& Wakabayashi I 2000 Glucocorticoids regulate pituitary growth hormone secretagogue receptor gene expression. Journal of Neuroendocrinology 12 481-485.

Tang-Christensen M, Vrang N, Ortmann S, Bidlingmaier M, Horvath TL \& Tschop M 2004a Central administration of ghrelin and Agouti-related protein (83-132) increases food intake and decreases spontaneous locomotor activity in rats. Endocrinology 145 4645-4652.

Tang-Christensen M, Vrang N, Ortmann S, Bidlingmaier M, Horvath TL \& Tschop M 2004b Central administration of ghrelin and Agouti-related protein (83-132) increases food intake and decreases spontaneous locomotor activity in rats. Endocrinology 145 4645-4652.

Thomas GB, Bennett PA, Carmignac DF \& Robinson ICAF 2000 Glucocorticoid regulation of growth hormone $(\mathrm{GH})$ secretagogue-induced growth responses and GH secretagogue receptor expression in the rat. Growth Hormone and IGF Research 10 45-52.

Tschop M, Smiley DL \& Heiman ML 2000 Ghrelin induces adiposity in rodents. Nature 407 908-913.

Tung YL, Hewson AK \& Dickson SL 2004 Glucocorticoid-dependent stimulation of adiposity and appetite by a ghrelin mimetic in the rat. European Journal of Endocrinology 150 905-911.

Tups A, Ellis C, Moar KM, Logie TJ, Adam CL, Mercer JG \& Klingenspor M 2004 Photoperiodic regulation of leptin sensitivity in the Siberian Hamster, phodopus sungorus, is reflected in arcuate nucleus SOCS-3 (suppressor of cytokine signaling) gene expression. Endocrinology 145 1185-1193.

Veyrat-Durebex C \& Alliot J 1997 Changes in pattern of macronutrient intake during aging in male and female rats. Physiology and Behavior 62 1273-1278.

Veyrat-Durebex C, Boghossian S \& Alliot J 1998 Age-related changes in adaptive mechanisms of macronutrient self-selection: evidence for a sexual dimorphism. Mechanisms of Ageing and Development 103 223-234.

Williams G, Bing C, Cai XJ, Harrold JA, King PJ \& Liu XH 2001 The hypothalamus and the control of energy homeostasis. Different circuits, different purposes. Physiology and Behavior 74 683-701.

Received in final form 26 April 2006

Accepted 26 May 2006

Made available online as an Accepted Preprint 23 June 2006 